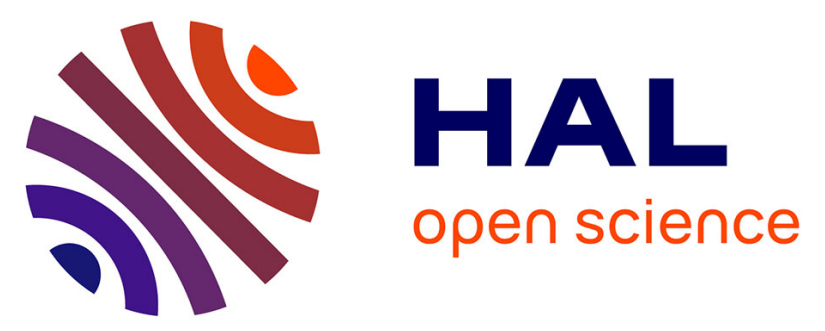

\title{
Clay mineralogy of surface sediments as a tool for deciphering river contributions to the Cariaco Basin (Venezuela)
}

Viviane Bout-roumazeilles, A. Riboulleau, E. Armynot Du Châtelet, L. Lorenzoni, N. Tribovillard, R. W. Murray, F. Müller-Karger, Y. M. Astor

\section{To cite this version:}

Viviane Bout-roumazeilles, A. Riboulleau, E. Armynot Du Châtelet, L. Lorenzoni, N. Tribovillard, et al.. Clay mineralogy of surface sediments as a tool for deciphering river contributions to the Cariaco Basin (Venezuela). Journal of Geophysical Research. Oceans, 2013, 118 (2), pp.750-761. 10.1002/jgrc.20079 . hal-03033110

\section{HAL Id: hal-03033110 https://hal.science/hal-03033110}

Submitted on 27 Jul 2021

HAL is a multi-disciplinary open access archive for the deposit and dissemination of scientific research documents, whether they are published or not. The documents may come from teaching and research institutions in France or abroad, or from public or private research centers.
L'archive ouverte pluridisciplinaire HAL, est destinée au dépôt et à la diffusion de documents scientifiques de niveau recherche, publiés ou non, émanant des établissements d'enseignement et de recherche français ou étrangers, des laboratoires publics ou privés. 


\title{
Clay mineralogy of surface sediments as a tool for deciphering river contributions to the Cariaco Basin (Venezuela)
}

\author{
V. Bout-Roumazeilles, ${ }^{1, *}$ A. Riboulleau, ${ }^{1}$ E. Armynot du Châtelet, ${ }^{1}$ L. Lorenzoni, ${ }^{3}$ N. \\ Tribovillard, ${ }^{1}$ R. W. Murray, ${ }^{2}$ F. Müller-Karger, ${ }^{3}$ and Y. M. Astor ${ }^{4}$
}

${ }^{1}$ Université Lille 1, Laboratoire Géosystèmes, UMR 8217 CNRS, bâtiment SN5, Villeneuve d'Ascq cedex, France.

${ }^{2}$ Department of Earth Science, Boston University, Boston, MA, USA.

${ }^{3}$ College of Marine Science, University of South Florida, Petersburg, FL, USA.

${ }^{4}$ La Salle Foundation of Natural Sciences, Margarita Marine Research Station, Margarita Island, Venezuela.

*Corresponding author: V. Bout-Roumazeilles, Université Lille 1, Laboratoire Géosystèmes, UMR 8217 CNRS, bâtiment SN5, Villeneuve d'Ascq cedex, France. (viviane.bout@univlille1.fr)

\begin{abstract}
The mineralogical composition of 95 surface sediment samples from the Cariaco Basin continental shelf and Orinoco delta was investigated in order to constrain the claymineral main provenance and distribution within the Cariaco Basin. The spatial variability of the data set was studied using a geo-statistical approach that allows drawing representative clay-mineral distribution maps. These maps are used to identify present-day dominant sources for each clay-mineral species in agreement with the geological characteristics of the main river watersheds emptying into the basin. This approach allows (1) identifying the most distinctive clay-mineral species/ratios that determine particle provenance, (2) evaluating the respective contribution of local rivers, and (3) confirming the minimal present-day influence of the Orinoco plume on the Cariaco Basin sedimentation. The Tuy, Unare, and Neveri Rivers are the main sources of clay particles to the Cariaco Basin sedimentation. At present, the Tuy River is the main contributor of illite to the western part of the southern Cariaco Basin continental shelf. The Unare River plume, carrying smectite and kaolinite, has a wide westward propagation, whereas the Neveri River contribution is less extended, providing kaolinite and illite toward the eastern Cariaco Basin. The Manzanares, Araya, Tortuga, and Margarita areas are secondary sources of local influence. These insights shed light on the
\end{abstract}


origin of present-day terrigenous sediments of the Cariaco Basin and help to propose alternative explanations for the temporal variability of clay mineralogy observed in previously published studies.

\section{Introduction}

The sedimentary record of the Cariaco Basin has been extensively used over the last decades for studying past environmental changes in the tropical regions [Peterson et al., 1991; Haug et al., 2001; Goñi et al., 2009; Peterson and Haug, 2006]. Several studies have recently focused on the terrigenous component of the sedimentary record to decipher the stratigraphic evolution of the fluvial/eolian supply to the basin at scales of seasonal, millennial, and orbital climate variations [Yarincik et al., 2000; Haug et al., 2001; Peterson and Haug, 2006; Martinez et al., 2007, 2010; Elmore et al., 2009]. Some of these studies focused on the geochemical composition of sediments [Haug et al., 2001; Martinez et al., 2010], while others investigated mineralogical content [Clayton et al., 1999; Black et al., 2009; Elmore et al., 2009]. A recent study provided the first regional geochemical data set of surface sediments from the Cariaco Basin and Orinoco Delta [Martinez et al., 2010]. This data set allows characterizing the regional patterns of the geochemical composition related to the main fluvial sources and assessing the relative contribution of these sources using linear mixing models. A mixing of upper crustal components with particle fluxes from local rivers and minor eolian inputs explained the main geochemical characteristics of the contents of modern sediment traps [Martinez et al., 2010]. The Martinez et al. [2010] study also supported the earlier conclusion of Müller-Karger and Varela [1990; Müller-Karger and Aparicio, 1994] and Lorenzoni [2005] that the Orinoco River does not contribute any significant sediment to the Cariaco Basin.

Clay mineralogical studies have been carried out in the Cariaco Basin to examine various timescales from orbital [Clayton et al., 1999] to millennial [Black et al., 2009] and even seasonal, as recorded by sediment traps [Elmore et al., 2009]. Clay mineral sources and distribution provide valuable information on the sediment propagation pathways and respective fluvial, eolian, and oceanic contributions to deep sedimentation. The present study conducts a detailed geospatial assessment of the continental shelf surrounding the Cariaco Basin and Orinoco delta clay mineral composition of surface sediments (Figure 1), using the samples collected by Martinez et al. [2010]. The choice of analyzing samples from the continental shelf offshore the main rivers rather than from the rivers themselves is based on the following facts: (1) the flow rates and suspended load from local rivers around Cariaco 
Basin are characterized by a high seasonal variability [Lorenzoni et al., 2009], and discrete river samples may not be representative of average supply, while sediment from the shelf likely integrates averaged River inputs; (2) previous studies evidenced that estuarine processes may alter the geochemical and mineralogical rivers signature [Chamley, 1989], while sediment from the shelf are likely representative of what is exported toward the basin; and (3) sediments from the emerged continental shelf were a source of terrigenous supply during glacial low sea level periods [Clayton et al., 1999]. The objectives are to identify the mineralogical signatures of the main rivers supplying sediment to the Cariaco Basin and to further clarify the spatial distribution and variability of terrigenous sediments deposited on the shelf surrounding the Cariaco Basin using geostatistics.

\section{Methods}

\subsection{Clay Mineralogy}

Seventy-three samples from the Cariaco shelf (Figure 1) and 22 samples from the Orinoco delta were analyzed for clay mineralogy. The Cariaco shelf was divided into 10 geographical areas to facilitate the quantification and visualization of inputs from different rivers [Martinez et al., 2010]. The samples were processed for X-ray diffraction (XRD) using a method adapted from Bout-Roumazeilles et al. [1999]. Weighted samples were first decarbonated using $0.1 \mathrm{~N}$ hydrochloric acid and then deflocculated by repeated washing with distilled water. The clay-size fraction $(<2 \mu \mathrm{m})$ was isolated by settling according to Stoke's law. The procedure was repeated until the total clay-size fraction was separated because of the very low amount of detrital fraction. The clay-size fraction was then concentrated by centrifugation, dried, and then weighted; an aliquot was oriented on glass slides. The clay-size fraction percentage (CSF) corresponds to the total dry clay-size fraction weight divided by the total dry sample weight and multiplied by 100 .

X-ray diagrams were obtained using a Bruker D4 Endeavor coupled with a Lynxeye detector (CuKa radiation and Ni filter). The voltage and tube current were respectively $30 \mathrm{kV}$ and $30 \mathrm{~mA}$. The analyses were processed using slow step-scanning procedures in order to improve the signal/ background ratio because of the low amount of clay-size fraction recovered for some samples. The XRD scanning was performed three times: on air-dried sample, after ethylene glycol saturation ( $12 \mathrm{~h}$ in high vacuum), and after heating at $490^{\circ}$ for 2 h. The goniometer scanned from $2.49^{\circ} 2 \theta$ to $32.49^{\circ} 2 \theta$ on all runs. Each clay mineral is determined according to its reticular distance (basal plus interlayer interval) on the XRD diagrams [Brown and Brindley, 1980]. Expandable mixed-layers minerals are characterized 
by a peak at $14.5 \AA$, which expands to $15-17 \AA$ after ethylene glycol saturation and retracts down to $10 \AA$ after heating. Distinction between smectite-rich mixed-layer minerals refers below as smectite and illite smectite mixed-layer minerals (IS). This separation was based on the position of the main peak after glycol saturation ( $17 \AA$ and $15 \AA$, respectively) and on the presence of "superstructure" at $29 \AA$ for the air-dried sample, expanding at $30 \AA$ after glycol saturation, which characterizes the presence of regular illite-smectite mixed-layer minerals. Illite is characterized by peaks at $10 \AA, 5 \AA$, and $3.33 \AA$, which remain unchanged on the three tests. Kaolinite is evidenced by peaks at $7.2 \AA$ and $3.58 \AA$ that disappear after heating, whereas peaks corresponding to chlorite (14 $\AA, 7.2 \AA, 4.75 \AA$, and $3.54 \AA$ ) remain stable on the three tests. Distinction between kaolinite and chlorite is based on step-scanned high-resolution between $3.60 \AA$ and $3.50 \AA$. Traces of paragonite $(9.7 \AA)$ and pyrophyllite $(9.21 \AA)$ were evidenced on some samples. Goethite, quartz, and feldspars are common components of the clay-size fraction. They are not included in the semi quantitative determination, as they are not considered to be clay minerals. Semi quantitative estimation of clay-mineral abundance is based on peak areas $[17 \AA$ (smectite) $+15 \AA$ (illite-smectite mixed layers) $+10 \AA$ (illite) $+7.2 \AA$ (kaolinite and chlorite)] as measured on the ethylene glycol saturated test using MacDiff W4.2.5 software summed to $100 \%$. The reproducibility error is estimated to be around $5 \%$. We compared our results with previously published data, some of them obtained using different analytical procedures or routines (for instance, using weighted correction factors); this might induce some bias. In order to get around this problem and to prevent any misinterpretation, we compare clay-mineral ratios rather than percentages. The illite to chlorite + kaolinite $\mathrm{I} /(\mathrm{C}+\mathrm{K})$ and illite to smectite $\mathrm{I} / \mathrm{S}$ ratios were calculated as follows:

$$
I /(C+K)=10 \AA / 7.2 \AA \text { and } I / S=10 \AA / 17 \AA
$$

The illite crystallinity and the Esquevin index were measured on the XRD diagrams. The illite crystallinity (in ${ }^{\circ} 2$ theta) corresponds to the full width at half maximum (FWHM) measured on the illite peak at $10 \AA$ [Chamley, 1989]. The illite crystallinity is inversely proportional to the metamorphism degree: a high crystallinity index indicates low metamorphism whereas low illite crystallinity index reflects a high metamorphism. The Esquevin index or chemical weathering index [Esquevin, 1969] is the ratio between the illite intensity measured at $5 \AA$ and the illite intensity measured at $10 \AA$.

\subsection{Geostatistics}


We quantified and modeled the spatial distribution of the clay-mineral assemblages using geostatistics [Wackernagel, 1988]. Classical statistics, which assumes completely independent measurements, is not suitable in this case for capturing and describing spatial dependency of a given variable. Geostatistics are used instead to illustrate the spatial variability of a variety of natural phenomena [e.g., Wackernagel, 1988; Haslett et al., 1991; Webster and Oliver, 2001; Hoover and Wolman, 2005; Jackson et al., 2007; Weindorf and Zhu, 2010]. Geostatistics take into account both the structured and random characteristics of spatially distributed variables to provide optimal estimations. It enables spatial relationships among sample values to be quantified and used for interpolation of values at non sampled locations in order to produce distribution maps.

Descriptive parameters including mean, median, standard deviation, extreme values, and coefficients of variation (CV), skewness, and kurtosis for each variable were calculated. $\mathrm{CV}$ represents the ratio of the standard deviation (SD) to the mean value multiplied by 100 . The normality of distribution was tested for each variable using the Lilliefors (KolmogorovSmirnov) test. All the descriptive parameters were calculated using R (v2.13) software with base and nortest packages (http://www.r-project.org). Geo-statistical analyses and mapping were performed using R software using geoR package [Ihaka and Gentleman, 1996].

The semi variance of a clay content is defined as half the expected squared difference between values at places $\mathrm{x}$ and $\mathrm{x}+\mathrm{h}$. A semi-variogram of each clay property was calculated by equation (1):

$$
\gamma(\mathrm{h})=\frac{1}{2 n_{\mathrm{h}}} \sum_{a=1}^{n_{\mathrm{h}}}\left[Z\left(x_{\mathrm{a}}+h\right)-Z\left(x_{\mathrm{a}}\right)\right]^{2}
$$

where $g(h)$ is the semi variance at lag distance $h$, nh is the number of observation pairs separated by $\mathrm{h}$, and $\mathrm{Z}\left(\mathrm{x}_{\mathrm{a}}\right)$ and $\mathrm{Z}\left(\mathrm{x}_{\mathrm{a}}+\mathrm{h}\right)$ give the paired values of the variable $\mathrm{Z}$ at two locations separated by $\mathrm{h}$. In the present study, the semivariograms were fitted using exponential and Gaussian models (equations (2) and (3), respectively), eventually mixed with a nugget model (equation (4)). The nugget represents variability at distances smaller than the typical sample spacing, including measurement and analytical error.

$$
\begin{aligned}
& \gamma(h)=C\left(1-\exp ^{\left(-\frac{-|h|}{a}\right)}\right) \\
& \gamma(h)=C\left(1-e^{-\left(\frac{h}{a}\right)^{2}}\right)
\end{aligned}
$$




$$
\gamma(h)=\left\{\begin{array}{l}
0 \text { if } h=0 \\
C \text { if } h>0
\end{array}\right.
$$

Based on the best-fitted semi-variogram model, maps for each variable are obtained using ordinary kriging interpolation. In the analysis, the threshold or sill value is the upper limit of the fitted semi-variogram model. The ratio of nugget to sill indicates the spatial dependency of the clay properties. The range of the semi-variogram represents the average distance through which the variable semi variance reaches its peak value. A small effective range implies a distribution pattern composed of small patches.

\section{Results}

The mineralogical analyses indicated that smectite, illite, chlorite, and kaolinite are the most common clay minerals of Cariaco Basin and Orinoco delta surface sediment samples, sometimes associated with regular illite-smectite mixed layers (Table 1). The composition of clay-mineral association - smectite (i.e., smectite in a strict sense and smectite- rich irregular mixed layers), illite, kaolinite, chlorite, and regular illite-smectite mixed layers (Table A-1 in the auxiliary material) — was statistically analyzed for each sample.1 For all parameters, the mean and the median are similar, with median values slightly lower than the mean for smectite, illite, and IS (Table 2), indicating that values are centered. An opposite pattern is observed for chlorite and kaolinite. IS are characterized by a high skewness (Table 2), implying that the frequency distributions are highly skewed, with numerous samples having low proportion (Figure A-1) and few having highest proportion. Most other clay minerals are symmetrically distributed. However, the Lilliefors test indicated

that smectite and CSF are significantly normally distributed, whereas I, C, K, and IS are not normally distributed (Table 2). Indeed, I and IS are characterized by high proportion of outliers; IS and K display the highest differences between mean and median. All clay species are characterized by high coefficients of variation $(\mathrm{CV}>25 \%)$ demonstrating substantial variability within the data sets. IS shows CV greater than 100 resulting from the occurrence of numerous outliers (Table 2, Figure A-1).

Spatial dependency is commonly accessed using the ratio of nugget $(\mathrm{C} 0)$ to sill $(\mathrm{C})$ expressed as percentage. This ratio was $<10 \%$ for clay minerals (Table 3 ). This means that a large part of the variance is spatially driven, suggesting that clay minerals distribution is strongly correlated to their geographical origin. The theoretical models used are Gaussian, 
except for smectite that is adjusted by an exponential model. Gaussian models indicate a continuous trend of data at low scale, whereas exponential models suggest a gradual increase of the semi variance as a function of distance, implying that spatial dependency declines at a steady rate with increasing distance. The need for only two theoretical models suggests that environmental processes controlling the clay mineral distribution are rather similar over the study area. However, high variability of ranges between mineral species implies different degrees of dispersion, likely resulting from hydrodynamic dispersion processes and/or specific mineral behavior. This result suggests that dispersion patterns for each clay species likely correspond to distinct river plumes. In agreement with these statistical results, each geographical region was depicted by its specific clay mineral association.

The Tuy River area is dominated by illite (Table 1, Figure 2). The concentration of illite is highest near the Tuy River mouth and decreases northeastward. Both $\mathrm{I} / \mathrm{C}+\mathrm{K})$ ratio (1.1) and I/S ratio (3.96) are high as indicated in Figure 3. According to the high clay content (approximately 13\% of total sediment), the Tuy River (Figure 4a) appears as one of the major clay-size particles supplier to south Cariaco Basin continental shelf, with a main northward propagation of the plume at present day (Figure 4c).

The Tuy-Tacarigua area is enriched in kaolinite and illite (Table 1, Figure 2). The area is characterized by low $\mathrm{I} /(\mathrm{C}+\mathrm{K})(0.54)$ and intermediate $\mathrm{I} / \mathrm{S}(2.04)$ ratios (Figure 3). The illite abundance increases westward, evidencing the increasing influence of the illite-rich Tuy River (Figure 4c). The moderate content in clay-size fraction (9\%) and its distribution pattern confirm the low propagation of the sediment plume toward the basin (Figure 4a).

The Unare South area is dominated by kaolinite and smectite (Table 1, Figure 2). The area is characterized by the lowest $\mathrm{I} /(\mathrm{C}+\mathrm{K})$ ratio observed $(0.38)$ and by a very low $\mathrm{I} / \mathrm{S}(0.79)$ ratio (Figure 3). The high proportion of clay-size fraction and its distribution pattern suggest efficient northward and northeastward propagations of the River plume (Figure 4a).

Kaolinite is the main component of the clay-mineral association in the Unare North area (Table 1, Figure 2), the second mineral is illite. The $\mathrm{I} /(\mathrm{C}+\mathrm{K})$ ratio $(0.56)$ and $\mathrm{I} / \mathrm{S}$ ratio (1.99) are low but higher than in the Unare south area, reflecting slightly higher proportion of illite.

Tortuga samples are rich in illite plus kaolinite. The Tortuga area is characterized by intermediate $\mathrm{I} /(\mathrm{C}+\mathrm{K})(0.99)$ and low $\mathrm{I} / \mathrm{S}(1.75)$ ratios. The very low CSF (2\%) suggests that supplies from this area could not significantly contribute to fine detrital sedimentation in the deep Cariaco Basin. Margarita samples are rich in smectite associated with illite. The Margarita area could neither be a major contributor of fine particles toward the basin since its 
CSF is also low (around 5\%) (Table 1; Figure 2). The Margarita area is characterized by slightly lower $\mathrm{I} /(\mathrm{C}+\mathrm{K})$ and $\mathrm{I} / \mathrm{S}$ ratios $(0.88$ and 0.74$)$ than the Tortuga area.

Kaolinite and illite largely dominate the clay-mineral fraction in the Neveri South area. Smectite and regular illite smectite mixed layer are rare (Table 1, Figure 2). As a result (Figure 3), the area displays very high I/S ratio (5.24) and low $\mathrm{I} /(\mathrm{C}+\mathrm{K})$ ratio (0.68). The $\mathrm{CSF}$ content (approximately 10\%) and distribution patterns (Figure 4a) suggest a moderate and geographically restricted propagation of the River plume.

The northern part of the Neveri area is also characterized by high proportion of kaolinite and illite, but smectite is more abundant (20\%) than in the southern area (Table 1), reflecting the influence of the Unare River plume (Figure $4 \mathrm{~b})$. The $\mathrm{I} /(\mathrm{C}+\mathrm{K})$ ratio $(0.61)$ is similar to the Neveri South area, whereas the I/S ratio is lower (1.50).

Illite dominates the clay-mineral fraction in the Manzanares area, in association with kaolinite and regular illite-smectite mixed layer (Table 1, Figures 2 and 4f). The $\mathrm{I} /(\mathrm{C}+\mathrm{K})$ ratio (1.83) and $\mathrm{I} / \mathrm{S}$ ratios (>8.66) are very high (Figure 3). The low CSF content (approximately 7\%) suggests that the Manzanares River clay supply toward the deep basin is of secondary importance.

Samples from the Araya area are mainly composed of illite associated with kaolinite. Smectite and regular illite smectite mixed-layer minerals are secondary components (Table 1, Figure 2). The $\mathrm{I} /(\mathrm{C}+\mathrm{K})$ ratio (1.01) is high, whereas the $\mathrm{I} / \mathrm{S}$ (1.91) ratio is low (Figure 3).

All samples from the Orinoco delta sediments, except one, are dominated by smectite (Table 1). Kaolinite, illite, and chlorite are secondary components. The Orinoco delta area is thus characterized by the lowest I/S ratio in the whole data set associated with low $\mathrm{I} /(\mathrm{C}+\mathrm{K})$ ratios (Figure 3). The Orinoco delta area (Figure 2) is potentially a large source for clay particles since it displays the largest clay-size fraction content $(15 \%)$.

\section{Discussion}

\subsection{Clay-Mineral Provenance}

[23] Illite is the dominant component of the clay-mineral fraction in the Manzanares (51\%) and Tuy (46\%) areas (Figure 5). It is noteworthy that the CSF (13.5\%) in the Tuy area is twice that of the Manzanares (7.7\%; Figure 2), consistent with their respective flow rates (Table A-2). This observation reflects specific erosional regimes resulting from environmental constrains; arid conditions dominate in the northeastern sector, whereas tropical savannah to intertropical climate in the southwestern sector likely favors summer precipitation and runoff (Figure A-1). The illite distribution map highlights a third potential 
source in the Tortuga area (Figure 4c), but according to the CSF content its potential impact on clay sedimentation within the Cariaco Basin should be at most of local influence. These two potential sources of illite are easily distinguished from each other because they plot on distinct domains on the $\mathrm{I} / \mathrm{S}$ versus $\mathrm{I} /(\mathrm{C}+\mathrm{K})$ diagram (Figure 3$)$. The locations of the main sources of illite are consistent with the main geological features of North Venezuela (Figure A-2). Illite - as well as chlorite — is a typically land-derived clay mineral that mainly results from physical weathering of old bedrocks and metamorphic domains [Bout-Roumazeilles et al., 1997]. Chlorite is considered a secondary mineral in the Cariaco Basin, showing low concentrations and little variations. It is often associated with illite in respect to their common origin. As a result, the Tuy River, which is the main contributor for illite, is also the main source of chlorite, with values up to $21 \%$ (Figures 2 and 4). Illite and chlorite are thought to derive from the metamorphic upland deposits [Mogollón and Bifano, 2000]. The northwestern and northeastern provinces of Venezuela consist of metamorphic domains (Figure A-2). On the northeastern area, the metamorphic rocks outcropping in the Araya peninsula are the main potential source of illite and of chlorite, to a lesser extent (Figure A-2), to the Cariaco Basin. The erosion products are mostly supplied to the Gulf of Cariaco (Figure 1) and may be further carried toward the basin by surface currents flowing out of the Gulf toward the Manzanares area [Mélières and Pérez-Nieto, 1973]. Nevertheless, the drainage to the Gulf of Cariaco is seasonally dependent, and the exchange of sediments between the shelf and the Gulf is likely limited. Alternatively, the sedimentary rocks from the Interior range outcropping in the Manzanares River watershed (Figure A-2) may be a source for illite (Figure 5) on the northeastern area - resulting in locally high illite concentration (Figure 4). Samples from the Orinoco delta and from the Tuy and Araya areas are characterized by low crystallinity index (Figure A-3), suggesting a provenance from metamorphized domains (epizone), in agreement with regional geology (Figure A-2). By contrast, the samples from the Unare area display high crystallinity index, reflecting a provenance from a drainage area dominated by low regional metamorphism (Figure A-2). The Esquevin index ranges from 0.2 in the Tuy area and Orinoco delta to 0.7 in the Manzanares and Neveri areas (Figure A-3). It has been shown that this index may be used to discriminate chemical weathering intensity [Liu et al., 2007], with low values reflecting $\mathrm{Mg}$ and Fe-rich illites produced by physical erosion, whereas high values correspond to Al-rich illite formed through hydrolysis. The illite deposited in the Tuy areas are typically produced via physical weathering of the Coastal range, whereas illite deposited in the Neveri and Unare areas derives from sedimentary formations subjected to hydrolyzing processes, in agreement with the environmental conditions of their drainage 
areas. In summary, the metamorphic rocks constituting the coastal range appear to be the main source of illite, via the Tuy River, for the northwestern side, whereas the Interior range is likely the main source of illite for the northeastern with some potential minor contribution from the Gulf of Cariaco (Figure A-2).

The kaolinite in the Cariaco Basin is widely distributed along the coast between the Tuy-Tac area and the Unare and Neveri Rivers (Figure 4e). The observed distribution of kaolinite is well constrained by the geological setting (Figure A-2). Kaolinite is common in equatorial and intertropical areas where hydrolysis processes promote its formation through intense washing of mobile elements [Chamley, 1989; Bout-Roumazeilles et al., 2007]. By contrast with superficial smectite-rich soils that preferentially develop under dry tropical climate, thick kaolinitic profiles develop under wet tropical climate [Thiry, 2000]. High amounts of kaolinite, associated with oxy-hydroxides, are redistributed from ancient, highly weathered, formations. The Mesozoic and Cenozoic sedimentary formations outcropping in the Unare drainage basin are considered to be a major source of kaolinite (Figure A-2) [Hackley et al., 2006; Guerrero- Alves et al., 2007]. Clay minerals from the Laguna de Unare are dominated by kaolinite [Bay, 1981; Longa and Bonilla, 1987], and the Unare River was recently identified as a major source of kaolinite to the Cariaco Basin [Elmore et al., 2009]. Although the Unare and Neveri Rivers display very similar kaolinite concentrations (38\%), their respective contribution may be distinguished using their distinct $\mathrm{I} / \mathrm{S}$ and $\mathrm{I} /(\mathrm{C}+\mathrm{K})$ ratios. The south Unare area is characterized by the lowest $\mathrm{I} /(\mathrm{C}+\mathrm{K})$ ratio $(0.38)$, whereas the Neveri south area displays higher $\mathrm{I} /(\mathrm{C}+\mathrm{K})$ ratio $(0.67)$. The $\mathrm{I} / \mathrm{S}$ ratio measured near the river mouths range from 0.79 near the Unare River to 5.24 for the Neveri River. The two rivers plot on rather distinct positions in a $\mathrm{I} /(\mathrm{C}+\mathrm{K})$ versus $\mathrm{I} / \mathrm{S}$ diagram (Figure 3$)$. The north Unare and Neveri areas show similar mineral ratios, evidencing a northeastward propagation of the Unare River plume (Figure 5), which is also depicted by smectite distributions (Figure 4b).

The distribution of the regular illite-smectite mixed layer minerals (Figures 4f) characterizes the eastern part of the Cariaco Basin (Figure 5) with maximum abundances in the Manzanares (>25\%) and in the Araya (up to 17\%) regions. The occurrence and relative abundance of IS in the easternmost part of the basin is likely related to the nearbyoutcropping Mesozoic and Cenozoic sedimentary rocks from the interior range that did not undergo severe metamorphism and thus promoted the preservation of these mixed layers within the clay-mineral fraction (Figure A-2). This well-constrained source is useful for deciphering the time evolution of the clay-mineral content from the Cariaco Basin sediment 
cores with respect to sea-level changes and/or modifications of the rainfall pattern over northern Venezuela (Figure 5).

\subsection{Amazon/Orinoco versus Local Rivers Contribution to Cariaco Basin Clay Sedimentation}

Our results evidence one potentially large remote source-namely, the Orinoco delta - and two major potential local sources - i.e., the Unare River and Margarita area — for smectite to Cariaco Basin clay sediments (Figures 2 and 4). The Margarita area is richer in smectite (35\% in average) than the Unare area (28\%), but its low clay-size content refutes any significant contribution toward the deep Cariaco Basin. The presence of smectite in the Unare area (Figure 6) reflects the geological settings of the Unare River watershed that is mainly composed of Mesozoic sedimentary formations (Figure A-2) where smectite is commonly associated with dominant kaolinite [Bay, 1981; Longa and Bonilla, 1987]. The contribution of the Amazon/Orinoco plume to the Cariaco sedimentation has been extensively investigated in the past few decades [Müller-Karger and Varela, 1990; Müller-Karger and Aparicio, 1994; Clayton et al., 1999; Peterson et al., 2000; Lorenzoni, 2005; Peterson and Haug, 2006; Martinez et al., 2010]. The Amazon and the Orinoco plumes are mixed along the coast of South America [Eisma et al., 1978; Müller-Karger et al., 1989]. At the Amazon River mouth (Figures 6 and S-2), the clay-mineral fraction contains rather similar proportions of kaolinite (35-42\%), illite (25-35\%), and smectite (27-32\%), kaolinite being slightly dominant [Gibbs, 1967; Parra et al., 1997; Vital et al., 1999; Patchineelam and de Figueiredo, 2000]. A relative enrichment in smectite is observed in suspended material transported alongshore South America by the Guiana current, probably resulting from differential settling processes [Chamley, 1989]. Along this path, the illite and kaolinite contents significantly decrease (Figure 6), while smectite proportion increases, representing up to $40 \%$ of the clay-mineral association $1400 \mathrm{~km}$ away from the Amazon River mouth [Gibbs, 1977; de Morais et al., 2006; Eisma and Marel, 1971]. By contrast, the clay mineralogy of the Orinoco River sediments (Figure 6) is dominated by illite (43-47\%) and kaolinite (27\%). The very low smectite content (7-13\%) is a characteristic feature of the Orinoco River [Parra et al., 1997; Pujos et al., 1997]. The clay-size fraction of the Orinoco delta contains 80\% Amazon River and 20\% Orinoco River contributions [Eisma et al., 1978]. As a result, the addition of some Orinoco-derived particles to the Amazon plume does not alter significantly the clay composition (Figure 6), even if it probably induces a local increase in the proportion of illite. Indeed, $100 \mathrm{~km}$ north of the Orinoco delta — at Dragon's mouth (Figures 1, 6, and S-2) — the 
clay-mineral association is dominated by smectite (35\%) and kaolinite (32\%), while illite is less abundant (21\%) [Pujos et al., 1997]. In agreement with these observations, the clay mineral fraction carried along with the Amazon/Orinoco plume would likely be enriched in smectite when entering the Cariaco Basin, and the plume should be highlighted by an increased proportion of smectite-rich clay-size particles in sediment, which is not supported by our results. Consistent with these observations, several arguments, including satellite imagery of the plume, salinity profiles, and surface sediment geochemistry, refute a significant detrital contribution from the Amazon/Orinoco plume toward the Cariaco Basin [Müller-Karger and Aparicio, 1994; Lorenzoni, 2005; Martinez et al., 2010].

The contribution to clay sedimentation by the Unare, Neveri, and Tuy rivers is of similar importance (Figure 2, Table 1). This is in agreement with previous estimation of river contributions and with their respective flow rates (Table A-2), which suggest that the major fine-grained terrigenous suppliers to the Cariaco Basin are the Tuy River for the western subbasin and the Unare and Neveri rivers for the eastern sub-basin (Figure 5) [Lorenzoni et al., 2009; Elmore et al., 2009; Martinez et al., 2010]. Our results indicate that the contributions of the Tuy and Unare rivers to deep sedimentation in the Cariaco Basin are quantitatively similar, although the Unare River (Figure 5) — despite its much larger drainage basin (Table A-2) - represents only $10 \%$ of the Tuy River annual sediment load [Milliman and Syvitski, 1992; Lorenzoni et al., 2009]. Indeed, the Tuy River plume mostly flows northwestward, following wind-driven surface currents, which limits its sedimentary supply toward the Cariaco Basin (Figure 5).

\subsection{New Insights on Previously Published Data}

Our new insights on clay-mineral provenance and on the respective contributions of local rivers are used to further examine the results from previous studies in the Cariaco Basin. Our results give support to previous interpretation and help propose alternative hypothesis that may also explain the observed variations in the clay-mineral records. Our data set might also be of help in future interpretation of clay-mineral variations recorded in Cariaco Basin sediments.

Elmore et al. [2009] analyzed the clay content in sediment traps from the CARIACO Time-series Station (Figure 1) in the eastern sub-basin and in core tops from the Unare shelf. Their results evidenced the dominance of kaolinite in sediment traps $(240 \mathrm{~m}$ depth and $1220 \mathrm{~m}$ depth) deriving from the Unare river, with enhanced supply of kaolinite occurring during major flooding events or seasonal rains [Elmore et al., 2009]. The proportion of illite within 
sediment traps was interpreted by the authors as reflecting the eolian supply to the basin. The observed seasonal variability was thus interpreted as reflecting enhanced fluvial and eolian inputs during the rainy season [Elmore et al., 2009]: enhanced river discharge occurs during summer and fall (i.e., the rainy season) when the Intertropical Convergence Zone lays in its northern position, which may also favor Saharan eolian supplies. But, according to previously published average clay mineralogy of Saharan eolian supply [Glaccum and Prospero, 1980], the illite content in sediment traps would correspond to a mean annual eolian contribution to Cariaco Basin deep sedimentation of $10 \%$. Similarly, the maximum concentration of illite (31\%) suggests a maximum eolian contribution of $25 \%$, which is unrealistic even if assuming starving fluvial supply. Our results indicate that the Neveri (34\% illite), Manzanares (51\% illite), or Tuy rivers (46\% illite) are major sources of illite within the Cariaco Basin. Due to the location of the mooring, any major supply from the Tuy River is unlikely. But the Neveri and Manzanares Rivers also experience enhanced detrital discharge during the rainy season when the precipitation belt extends eastward. The variability of illite in sediment traps may also and alternatively be explained by seasonally forced enhanced contribution from one of these two rivers.

Clayton and coworkers [1999] examined the clay mineral content of site ODP1002 (Figure 1) and found modifications of the illite versus smectite ratios (referred to as illitesmectite mixed layers in the study) at orbital timescale, which they attributed to varying contributions of the Amazon-Orinoco system. When plotted in the $\mathrm{I} / \mathrm{S}$ versus $\mathrm{I} /(\mathrm{C}+\mathrm{K})$ diagram (Figure 3), most samples from the ODP Site 1002 align next to a mixing line between the Unare River (smectite-rich) and Tuy River (illite-rich) end-members. The ODP data set displays the whole range of variability between these two end-members. Sediments deposited during glacial periods plot near to the Unare River, whereas samples deposited during interglacial periods plot near the Tuy River. These results confirm a dominant terrigenous supply from local rivers during glacial periods as initially proposed by Clayton et al. [1999]. Our results also suggest that the Unare River is likely the main supplier to sedimentation at the ODP site 1002 during glacials, reflecting enhanced sediment supply from the southern continental shelf to the deep western Cariaco sub-basin during low sea level $(<100 \mathrm{~m})$. The fact that interglacial samples also align on the mixing line between the Unare River and the Tuy River end-members does not give support to a major contribution from the Orinoco plume during interglacials. Glacial sediment was composed of $70 \%$ smectite associated with $13 \%$ illite, $13 \%$ kaolinite, and $6 \%$ chlorite $(\mathrm{I} / \mathrm{S}=0.9$ and $\mathrm{I} / \mathrm{C}+\mathrm{K}=0.5)$ [Clayton et al., 1999]. Our surface data suggests that the glacial/interglacial variability may 
also be explained by variations of local river contributions by changing the respective contribution of the Unare River versus Tuy River or versus Manzanares River. Although the Tuy River mainly discharges toward the western sub-basin, its plume has been noted to travel northeastward during certain times of the year, as seen with satellite ocean color imagery (Lorenzoni, unpublished data) and evidenced through numerical circulation modeling [Alvera- Azcárate et al., 2009]. The ODP1002 site was located on the central saddle, likely receiving more influence from the Tuy River than the Manzanares. The clay-mineral compositions of both glacial and interglacial samples from the ODP 1002 site may be reproduced by linearly mixing the supplies of the Tuy and Unare rivers (Figure 3 ). These observations suggest that high sea level may promote efficient offshore mixing of various sources during interglacials, whereas low sea level during glacials may favor specific supply from the Unare southern area toward the deep western Cariaco sub-basin. Alternatively, climatically induced latitudinal migration of the precipitation belt might also be responsible for the observed variability by promoting rainfall on the Coastal range and thus increasing illite supply during interglacial, whereas a southward position of the precipitation belt would promote smectite supply from the Unare drainage area. Moreover, this new interpretation is consistent with data indicating that the Amazon/Orinoco plume has no influence in the Cariaco Basin [Müller-Karger and Aparicio, 1994; Lorenzoni, 2005; Martinez et al., 2010].

Finally, our clay-mineral analyses were performed on the same samples as the ones studied by Martinez et al. [2010] and provide the opportunity to compare mineral and geochemical detrital proxies. Geochemical data indicated that eastern and northern areas were characterized by lower terrigenous supply than the southern area, which is consistent with our estimation of the terrigenous clay contribution based only on the clay-size particle content. Illite distribution is very similar to the distribution of $\mathrm{K} / \mathrm{Al}$, which is consistent with the fact that illite is a K-rich clay mineral. The IS distribution is similar to both $\mathrm{La} / \mathrm{Al}$ and $\mathrm{Th} / \mathrm{Al}$ spatial distributions, likely reflecting the chemical affinity of expandable clay minerals for trace elements or a similar geographic origin for the trace elements-bearing minerals and IS. Surprisingly, the spatial distribution of smectite is not directly comparable with any elemental ratio, although some similarity is observed with the Sc/Al ratio spatial distribution. The results from Martinez et al. [2010] suggested that three factors, respectively related to Al, Sc, $\mathrm{K}$, and $\mathrm{Rb}$ (factor 1), to $\mathrm{La}$ and $\mathrm{Th}$ (factor 2), and to $\mathrm{Ti}$ and $\mathrm{Cr}$ (factor 3), successfully depicted the terrigenous distribution around the basin. The spatial distribution of factor 1 seems to reflect our variations of both illite and kaolinite. This is consistent with the fact that this factor is mainly driven by $\mathrm{Al}$ and $\mathrm{K}$, respectively linked to kaolinite- i.e., a highly 
hydrolyzed mineral enriched in $\mathrm{Al}$ - and to illite-i.e., a K-rich mineral. The distribution of the second factor displays some similarity with the spatial distribution of our mixed layers in the Cariaco Basin. The third factor does not seem to be directly comparable with any clay mineral, although its spatial distribution displays some similarities with that of smectite. Moreover, our clay-mineral data are consistent with the zones identified by Martinez et al. [2010] and allowed a clearer differentiation of the Neveri-Unare region from MargaritaAraya. Any differences between the chemical and mineralogical approaches result from the fact that chemical elements are not distributed as individual species but belong to different mineral structures among which are clay minerals. In this sense, the clay-mineral distribution maps are complementary to the geochemical approach, even providing more straightforward information.

\section{Conclusions}

The clay-mineral composition of surface sediments from the Cariaco Basin and the Orinoco delta was studied using XRD routine procedures. The spatial variability of the clay mineral distribution in the Cariaco Basin was specifically investigated using geo-statistical tools. These approaches generate distribution maps for each clay-mineral species and characterize specific clay association for each geographical area. According to geological settings, it was possible to constrain the mineralogical characteristics of the main river supplies and give estimation of their respective potential contribution to the Cariaco Basin deep sedimentation:

Smectite is the main component of the Orinoco delta supply, whereas the Unare River is a secondary source. The Tuy and Manzanares rivers are the main sources for illite in the western and eastern sub-basins, respectively. The Unare and Neveri rivers mainly supply kaolinite to the Cariaco Basin southern continental shelf. The presence of regular illite smectite mixed layers characterizes the eastern part of the Basin, tracing a specific provenance from the Manzanares and Araya areas.

At present day, the Tuy, Unare, and Neveri rivers are quantitatively the main sources of clay minerals to the Cariaco Basin southern continental shelf. The distribution maps indicate that the Tuy River is mainly propagating northward; the Unare River plume has a wide propagation toward the northeastern part of Cariaco Basin; and the Neveri River plume has a 
proximal influence, being diluted by the Unare River plume onto the shelf. The Manzanares and Araya areas are secondary contributors to the eastern part of the Cariaco Basin deep sedimentation.

- $\quad$ The peculiar mineralogical signature of the Orinoco delta and distribution maps rule out any major contribution toward the Cariaco Basin.

Based on our new data set, we propose alternative scenarios for explaining the clay-mineral variability from previously published studies, focusing on varying contributions of local rivers rather than involving remote eolian supply.

- $\quad$ Finally, clay minerals appear to be a useful tool for deciphering the past and present-day complex river supplies in the Cariaco Basin.

\section{Acknowledgments}

Deny Malengros is acknowledged for his help in running the samples. Rachel Scudder is warmly thanked for preparing and sending - twice-the samples. The samples used in this study were available thanks to the CARIACO project. We thank Miguel Goñi for his work as an Editor and two anonymous reviewers who helped us improve significantly our paper. The National Science Foundation (NSF Grants OCE-9729284 and OCE-9216626 to FMK and OCE-9415790, OCE-9711318, OCE-9730278 and OCE-0118491 to MIS) and the Consejo Nacional de Investigaciones Cientificas y Tecnológicas (CONICIT, VENEZUELA, Grant 96280221) and Fondo Nacional de Ciencia y Tecnología (FONACIT, Venezuela, Grant 2000001702) supported this work.

\section{References}

Alvera-Azcárate, A., A. Barth, and R. H. Weisberg (2009), A nested model of the Cariaco Basin (Venezuela): Description of the basin's interior hydrography and interactions with the Open Ocean, Ocean Dyn., 59, 97-120.

Bay, A.V. C. (1981), Analisis de Sedimentos y Solidos Suspendidos de la Laguna de Unare, Facultad de Ciencias, Escuela de Química, T.E.G., Universidad Central de Venezuela, Venezuela.

Biscaye, P. E. (1965), Mineralogy and sedimentation of recent deep-sea clay in the Atlantic ocean and adjacent seas and oceans, Geol. Soc. Am. Bull., 76, 803-832. 
Black, D. E., S. Hameed, and L. C. Peterson (2009), Long-term tidal cycle influences on a Late-Holocene clay mineralogy record from the Cariaco Basin, Earth Planet. Sci. Lett., 279, 139-146, doi:10.1016/j.eps1.2008.12.040.

Bout-Roumazeilles, V., P. Debrabant, L. Labeyrie, H. Chamley, and E. Cortijo (1997), Latitudinal control of astronomical forcing parameters on the high resolution clay mineral distribution in the 45 degrees-60 degrees $\mathrm{N}$ range in the North Atlantic Ocean during the past 300,000 years, Paleoceanography, 12, 671-686.

Bout-Roumazeilles, V., E. Cortijo, L. Labeyrie, and P. Debrabant (1999), Clay mineral evidence of nepheloid layer contributions to the Heinrich layers in the northwest Atlantic, Palaeogeogr., Palaeoclimatol., Palaeoecol., 146, 211-228.

Bout-Roumazeilles, V., N. Combourieu Nebout, O. Peyron, E. Cortijo, A. Landais, V. Masson-Delmotte (2007), Connection between South Mediterranean climate and North African atmospheric circulation during the last 50,000 yr BP North Atlantic cold events, Quat. Sci. Rev., 26, 3197-3215, doi:10.1016/j.quascirev.2007.07.015.

Brown, G., and G. W. Brindley (1980), X-ray diffraction procedures for clay mineral identification in Crystal Structures of Clay Minerals and Their X-ray Identification, edited by G. W., Brindley, and G., Brown, pp. 305-359, Mineralogical Society, London.

Chamley, H. (1989), Clay Sedimentology, Springer Verlag, Berlin.

Clayton, T., R. B. Pearce, and L. C. Peterson (1999), Indirect climatic control of the clay mineral composition of Quaternary sediments from the Cariaco Basin, northern Venezuela (ODP Site 1002), Marine Geol., 161, 191-206.

de Morais, J., M. Tintelnot, G. Irion, and L. Souza Pinheiro (2006), Pathways of clay mineral transport in the coastal zone of the Brazilian continental shelf from Ceará to the mouth of the Amazon River, Geo-Marine Lett., 26, 16-22, doi:10.1007/S00367-005-0011-1.

Debrabant, P., M. Lopez, and H. Chamley, (1997), Clay mineral distribution and significance in quaternary sediments of the Amazon Fan, in Proceedings of the Ocean Drilling Program, Scientific Results, 155, edited by R. D. Flood, D. J. W. Piper, A. Klaus, and L. C. Peterson, Texas A\&M University, Ocean Drilling Program, College Station, TX, United States, pp. $177-192$.

Eisma, D., and H. W. Marel (1971), Marine muds along the Guyana coast and their origin from the Amazon basin, Contrib. Mineral. Petrol., 31, 321-334.

Eisma, D., S. J. Van Der Gaast, J. M. Martin, and A. J. Thomas (1978), Suspended matter and bottom deposits of the Orinoco delta: Turbidity, mineralogy and elementary composition, Netherlands J. Sea Res., 12, 224-251. 
Elmore, A. C., R. C. Thunell, R. Styles, D. Black, R.W. Murray, N. Martinez, and Y. Astor (2009), Quantifying the seasonal variations in fluvial and eolian sources of terrigenous material to Cariaco Basin, Venezuela, J. South Am. Earth Sci., 27, 197-210, doi:10.1016/j.sames.2008.11.002.

Esquevin, J. (1969), Influence de la composition chimique des illites sur cristallinite, Bull. Cent. Rech. Pau, SNPA, 3, 147-153.

Gibbs, R. J. (1967), The geochemistry of the Amazon River system: Part I, The factors that control the salinity and the composition and concentration of the suspended solids, Geol. Soc. Am. Bull., 78, 1203-1232.

Gibbs, R. J. (1977), Clay mineral segregation in the marine environment, J. Sediment. Res., 47, 237-243.

Glaccum, R. A., and J. M. Prospero (1980), Saharan aerosols over the tropical North Atlantic-Mineralogy, Marine Geol., 37, 295-321.

Goñi ,M.A., H. Aceves, B. Benitez-Nelson, E. Tappa, R. Thunell, D. E. Black, F. MullerKarger, Y. Astor, and R. Varela (2009), Oceanographic and climatologic controls on the compositions and fluxes of biogenic materials in the water column and sediments of the Cariaco Basin over the Late Holocene, Deep Sea Res. Part I: Oceanogr. Res. Papers, 56, 614 640, doi:10.1016/j.dsr.2008.11.010.

Guerrero-Alves, J. P., I. Pla-Sentis, R. G. Camacho, Á. Valera, and J. Ferrer (2007), Génesis de un suelo salino-sódico de Tucupido, estado Guárico- Venezuela, Agronomía Tropic., 57, 171-188.

Hackley, P. C., F. Urbani, A. W. Karlsen, and C. P. Garrity (2006), Mapa Geológico de Venezuela a Escala 1:750,000.

Haug, G. H., K. A. Hughen, D. M. Sigman, L. C. Peterson, and U. Rohl (2001), Southward migration of the intertropical convergence zone through the Holocene, Science, 293, 1304 1308.

Haslett, J., R. Bradley, P. S. Craig, G. Wills, and A. R. Unwin (1991), Dynamic graphics for exploring spatial data, with application to locating global and local anomalies, The Am. Statistician, 45, 234-242.

Hoover, K. A., and M. G. Wolman (2005), Beyond the semivariogram: Patterns, scale, and hydrology in a semi-arid landscape, Adv. Water Res., 28, 885-898, doi:10.1016/j.advwatres.2005.02.006.

Ihaka, R., and R. Gentleman (1996), R: A language for data analysis and graphics, J. Comput. Graph. Stat., 5, 299-314. 
Jackson, R. D., M. M. Bell, and C. Gratton (2007), Assessing ecosystem variance at different scales to generalize about pasture management in southern Wisconsin, Agr Ecosyst Environ, 122, 471-478, doi: 10.1016/ j.agee.2007.03.004.

Liu, Z., C. Colin, W. Huang, K. P. La, S. Tong, Z. Chen, and A. Trentesaux (2007), Climatic and tectonic controls on weathering in South China and the Indochina Peninsula: Clay mineralogical and geochemical investigations from the Pearl, Red, and Mekong drainage basins, Geochem. Geophys. Geosyst., 8, Q05005, doi:10.1029/2006GC001490.

Longa, Y., and J. Bonilla (1987), Caracterizacion quimica de los sedimentos de la interfase de la Laguna de Unare, Venezuela, Bol. Inst. Oceanogr. Venezuela, Universidad de Oriente, 26, 81-89.

Lorenzoni, L. (2005), The influence of local rivers on the Eastern Cariaco Basin, Venezuela, $\mathrm{PhD}$ thesis, College of Marine Science, University of South Florida, Miami, USA.

Lorenzoni, L.,R. C. Thunell, C. R. Benitez-Nelson, D. Hollander, N. Martinez, E. Tappa, R. Varela, Y. Astor, and F. E. Muller-Karger (2009), The importance of subsurface nepheloid layers in transport and delivery of sediments to the eastern Cariaco Basin, Venezuela, Deep Sea Res. Part I: Oceanogr. Res. Papers, 56, 2249-2262, doi:10.1016/j.dsr.2009.08.001.

Martinez, N. C., R. W. Murray, R. C. Thunell, L. C. Peterson, F. Muller- Karger, Y. Astor, and R. Varela (2007), Modern climate forcing of terrigenous deposition in the tropics (Cariaco Basin, Venezuela), Earth Planet. Sci. Lett., 264, 438-451, doi:10.1016/j.eps1.2007.10.002.

Martinez, N. C., R. W. Murray, R. C. Thunell, L. C. Peterson, F. Muller- Karger, L. Lorenzoni, Y. Astor, and R. Varela (2010), Local and regional geochemical signatures of surface sediments from the Cariaco Basin and Orinoco Delta, Venezuela, Geology, 38, 159162, doi:10.1130/G30487.1.

Milliman, J. D., and J. P. M. Syvitski (1992), Geomorphic/tectonic control of sediment discharge to the ocean: The importance of small mountainous rivers, J. Geol., 100, 520-540.

Mogollón, J. L., and Bifano, C. (2000), Tracking the metal distribution in the tropical Valencia lake catchment: Soil, rivers and lake, Environ. Geochem. Health, 22, 131-153.

Mélières, F., and H. Pérez-Nieto (1973), Les minéraux argileux des sédiments récents du Golfe de Cariaco (Venezuela), Bull. Gr. Fr. Argiles, 25, 65-78.

Müller-Karger, F. E., and R. J. Varela (1990), Influjo el Rio Orinoco en el Mar Caribe: Observaciones con el CZCS desde el espacio, Mem. Soc. Cien. Nat. La Salle 49, 361-390.

Müller-Karger, F. E., and R. Aparicio (1994), Mesoscale processes affecting phytoplankton abundance in the southern Caribbean Sea, Continent. Shelf Res., 14, 199-221. 
Müller-Karger, F. E., C. R. McCain, T. R. Fisher, W. E. Esaias, and R. Varela (1989), Pigment distribution in the Caribbean Sea: Observations from space, Progr. Oceanogr., 23, 23-69.

Parra, M., J.-C. Faugères, F. Grousset, and C. Pujol (1997), Sr-Nd isotopes as tracers of finegrained detrital sediments: The South-Barbados accretionary prism during the last $150 \mathrm{kyr}$, Marine Geol., 136, 225-243.

Patchineelam, S. M., and A. G. de Figueiredo (2000), Preferential settling of smectite on the Amazon continental shelf, Geo-Marine Lett., 20, 37-42.

Peterson, L. C., J. T. Overpeck, N. G. Kipp, and J. Imbrie (1991), A highresolution late Quaternary upwelling record from the anoxic Cariaco Basin, Venezuela, Paleoceanography, 6, 99-119.

Peterson, L. C., G. H. Haug, K. A. Hughen, and U. Rohl (2000), Rapid changes in the hydrologic cycle of the tropical Atlantic during the last glacial, Science, 290, 1947-1951.

Peterson, L. C., and G. H. Haug (2006), Variability in the mean latitude of the Atlantic Intertropical Convergence Zone as recorded by riverine input of sediments to the Cariaco Basin (Venezuela), Palaeogeogr., Palaeoclimatol., Palaeoecol., 234, 97-113, doi:10.1016/j.palaeo.2005.10.021.

Pujos, M., J. Monente, C. Latouche, and N. Maillet (1997), Origine de la sédimentation dans le delta de l'Orénoque et le golfe de Paria (Venezuela): Impact du système dispersif amazonien, Oceanol. Acta, 20, 799-809.

Rühlemann, C., B. Dickmann, S. Mulitza, and M. Frank (2001), Late Quaternary changes of western equatorial Atlantic surface circulation and Amazon lowland climate recorded in Ceará Rise deep-sea sediments, Paleoceanography, 16, 293-305.

Thiry, M. (2000), Palaeoclimatic interpretation of clay minerals in marine deposits: An outlook from the continental origin, Earth-Sci. Rev., 49, 201-221.

Vital, H., K. Stattegger, and C.-D. Garbe-Schoenberg (1999), Composition and trace-element geochemistry of detrital clay and heavy-mineral suites of the lowermost Amazon River: A provenance study, J. Sediment. Res., 69, 563-575.

Wackernagel, H. (1988), Geostatistical techniques for interpreting multivariate spatial information, in Quantitative Analysis of Mineral and Energy Resources, NATO ASI Series C 223, edited by C. F. Chung, et al., pp. 393-409, Reidel, Dordrecht, Netherland.

Webster, R., and M. A. Oliver (2001), Geostatistics for Environmental Scientists, John Wiley \& Sons, Chichester, UK. 
Weindorf, D. C., and Y. Zhu (2010), Spatial variability of soil properties at Capulin Volcano, New Mexico, USA: Implications for sampling strategy, Pedosphere, 20, 185-197.

Yarincik, K. M., R. W. Murray, and L. C. Peterson (2000), Climatically sensitive eolian and hemipelagic deposition in the Cariaco Basin, Venezuela, over the past 578,000 years: Results from Al/Ti and K/Al, Paleoceanography, 15, 210-228, doi:10.1029/1999PA900048. 


\section{Figure captions}
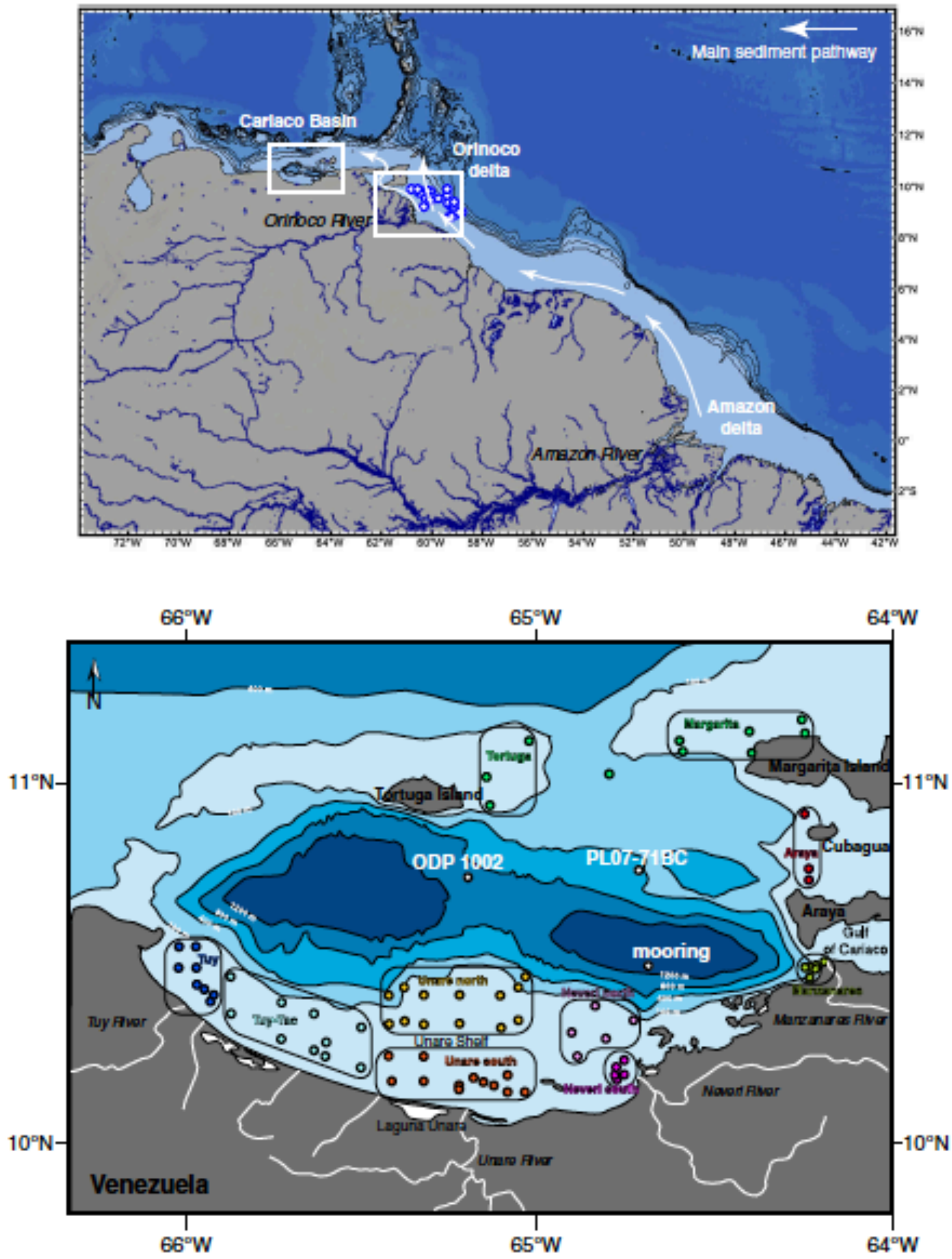

Figure 1. Bathymetry of the Cariaco Basin and of the Orinoco delta. Location of the samples studied, main geographical areas as referred in the text. Respective position of the ODP site1002 and mooring of the sediment traps referred in the text. 



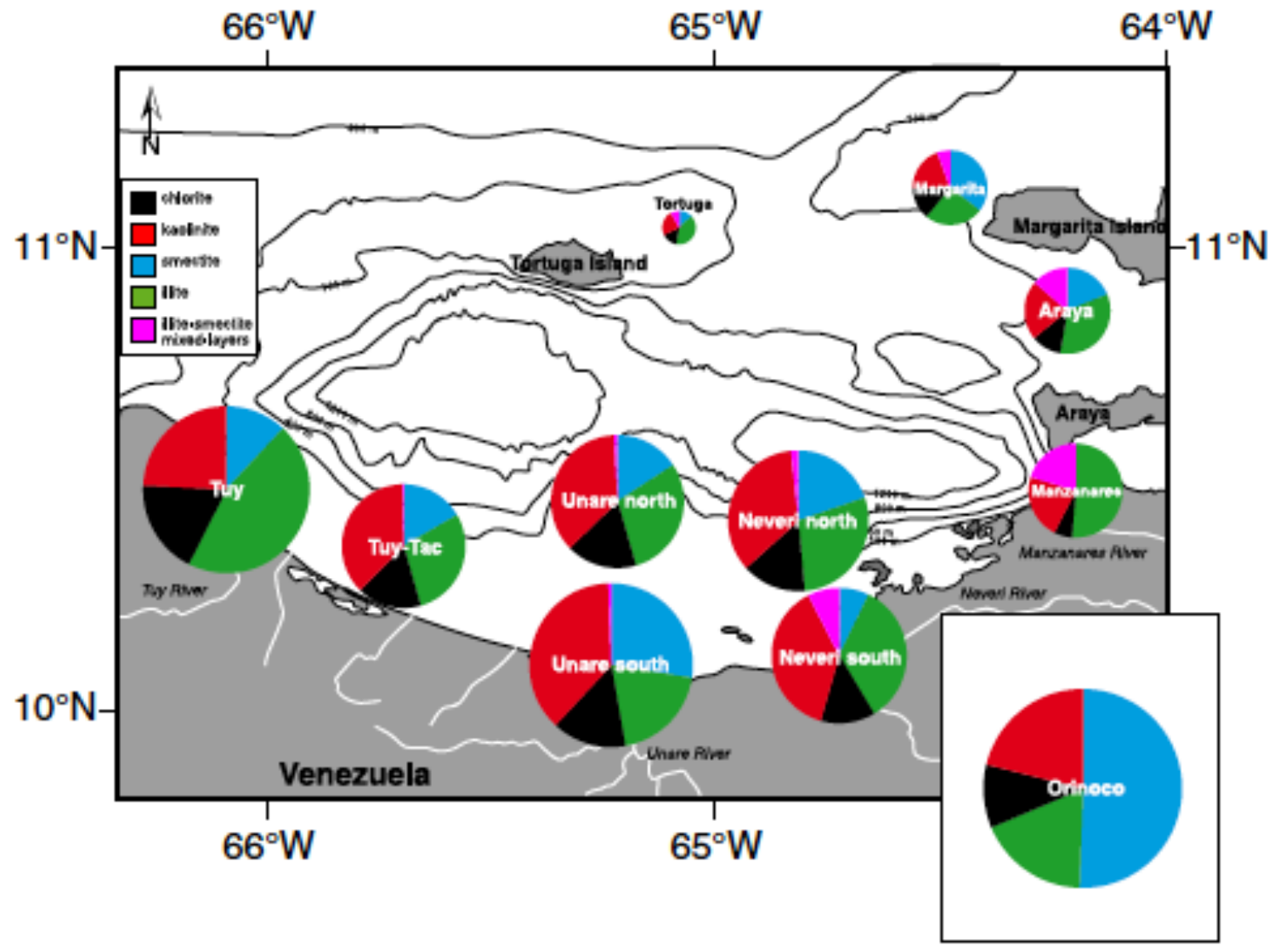

Figure 2. Averaged clay composition in the geographical areas. The size of the diagrams is proportional to the clay size fraction abundance. 


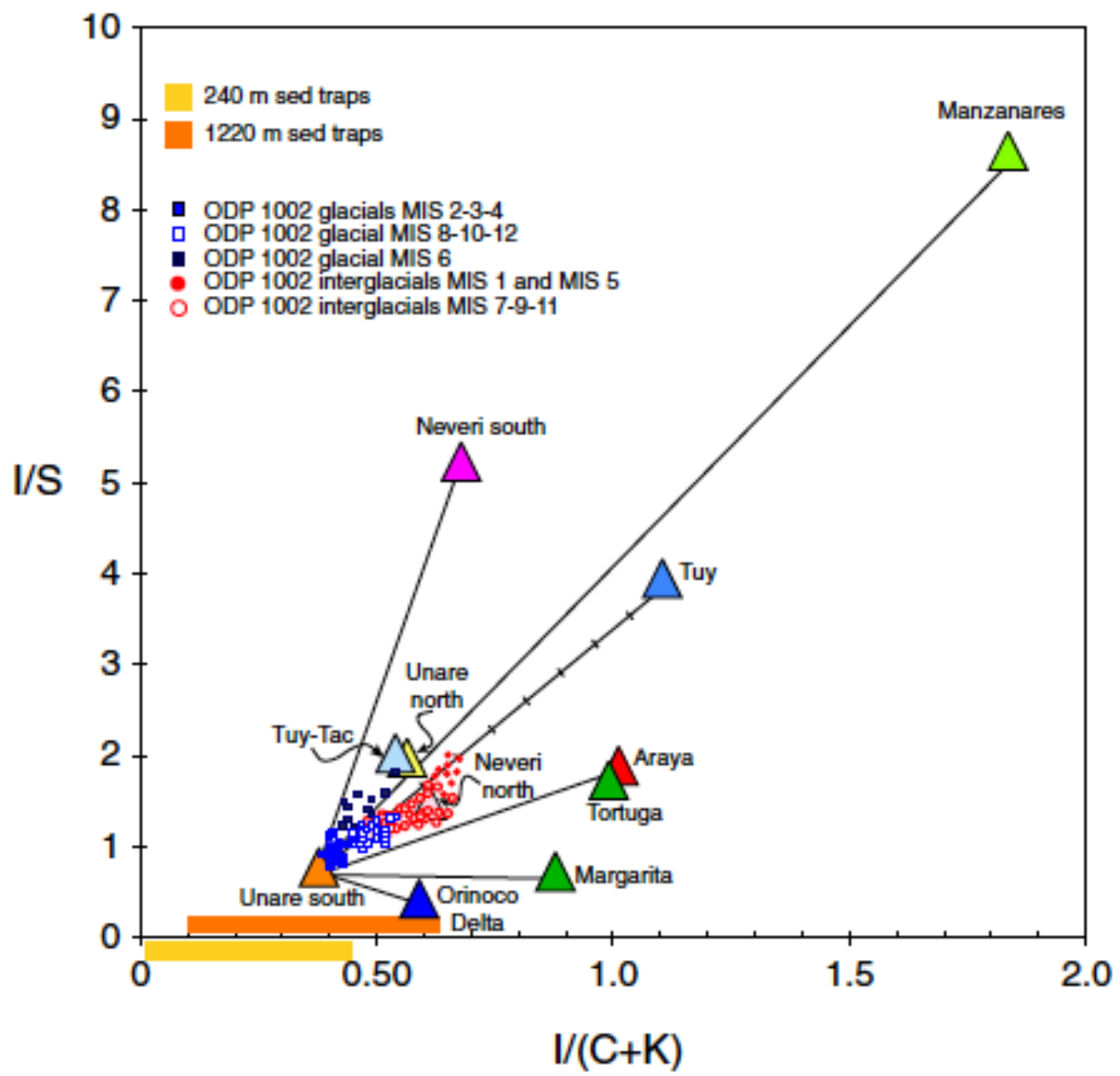

Figure 3. Position of the main geographical areas in a binary diagram: $\mathrm{I} / \mathrm{S}=$ illite/smectite ratio, $\mathrm{I} /(\mathrm{C}+\mathrm{K})=\mathrm{illite} /($ chlorite + kaolinite) ratio. ODP 1002 samples from glacial and interglacial stages from Clayton et al. [1999]; sediment traps from Elmore et al. [2009]. 

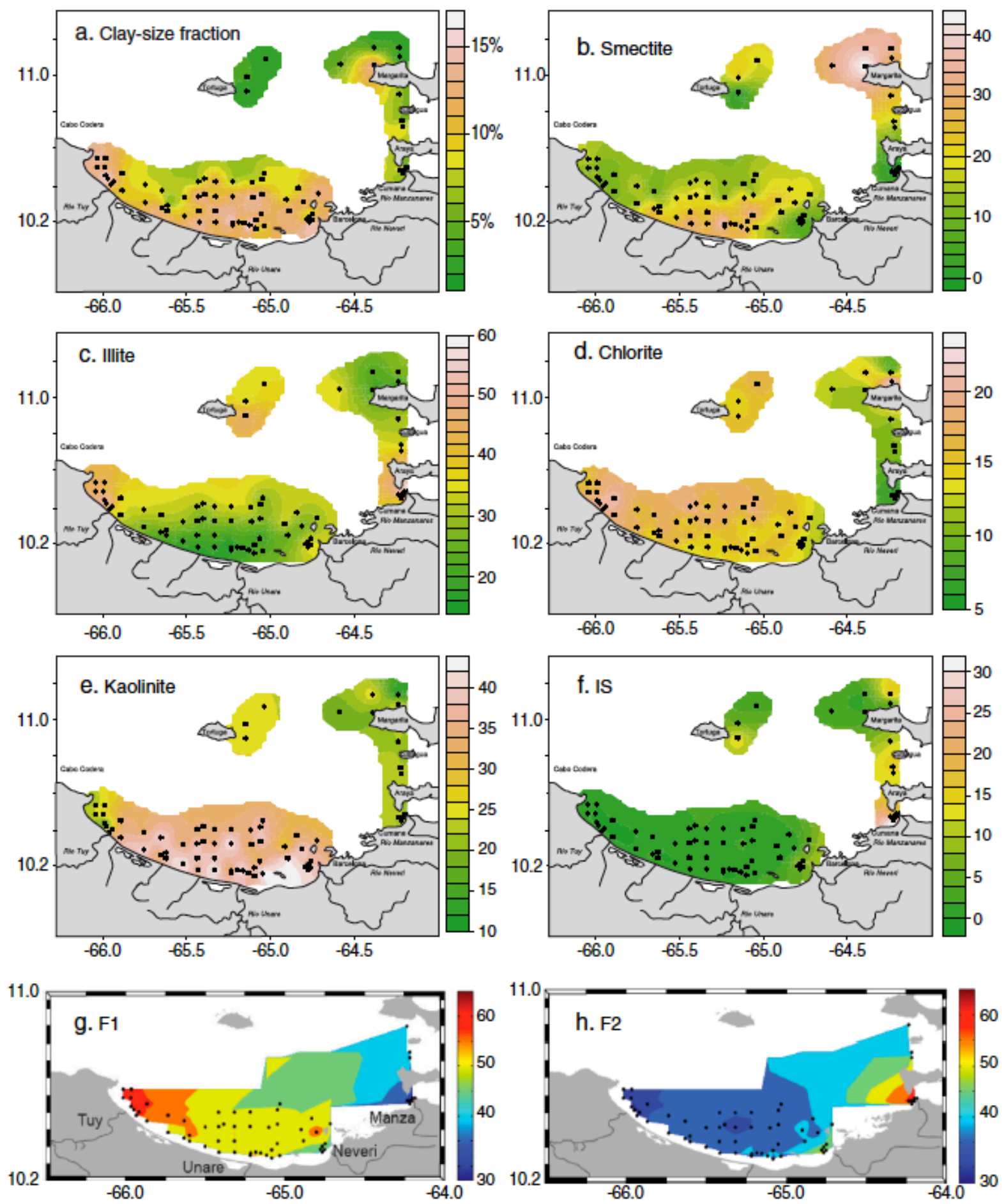

Figure 4. Interpolation maps of clay minerals using ordinary kriging. Distribution of the main clay mineral species in the Cariaco Basin: (a) clay-size fraction (\% sediment), (b) illite, (c) chlorite, (d) smectite, (e) kaolinite, (f) regular illite-smectite mixed layers, (g) distribution of factor F1 (\%) as defined by Martinez et al. [2010], (h) Distribution factor F2 (\%) as defined by Martinez et al. [2010]. 


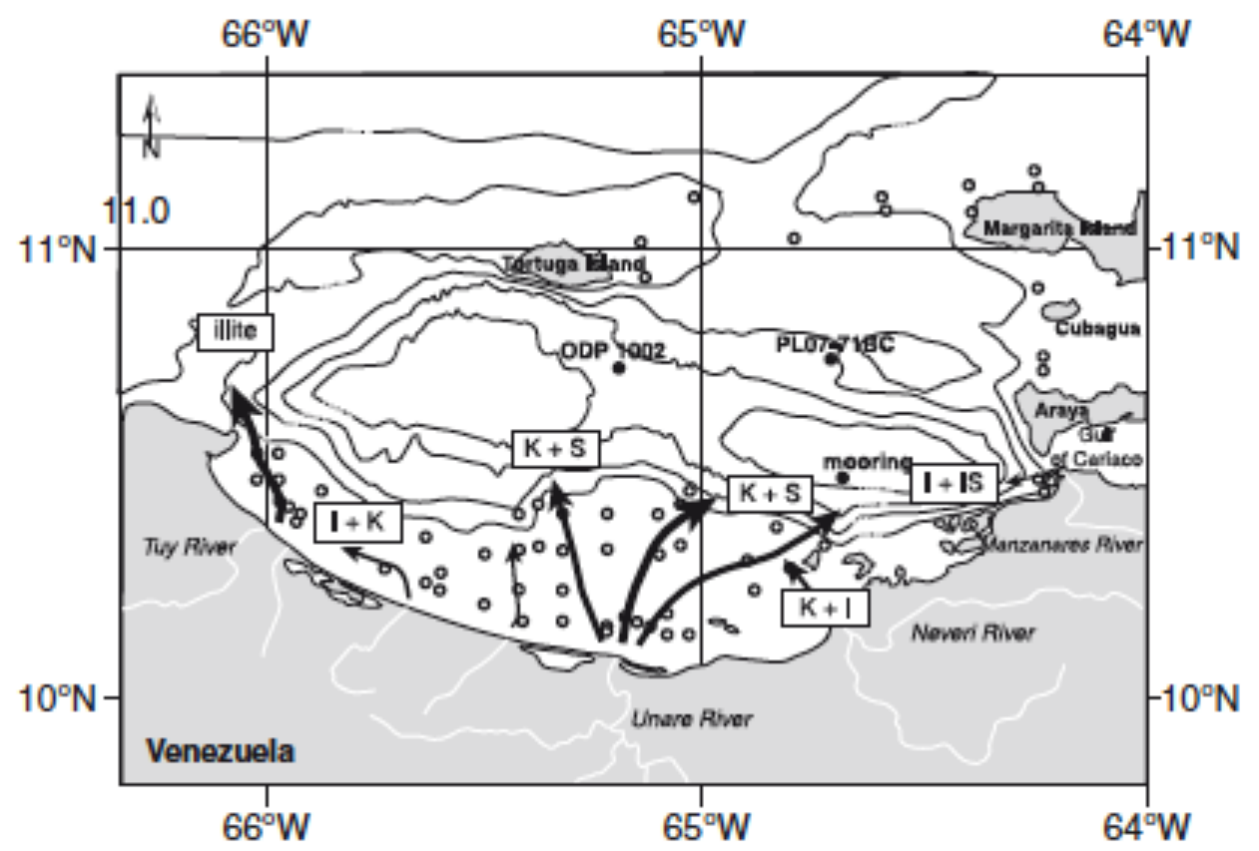

Figure 5. Main mineralogical composition and distribution patterns of the main Cariaco Basin tributaries onto the continental shelf. $\mathrm{I}=$ illite, $\mathrm{K}=$ kaolinite, $\mathrm{S}=$ smectite, $\mathrm{IS}=$ illite-smectite mixed-layer minerals. 


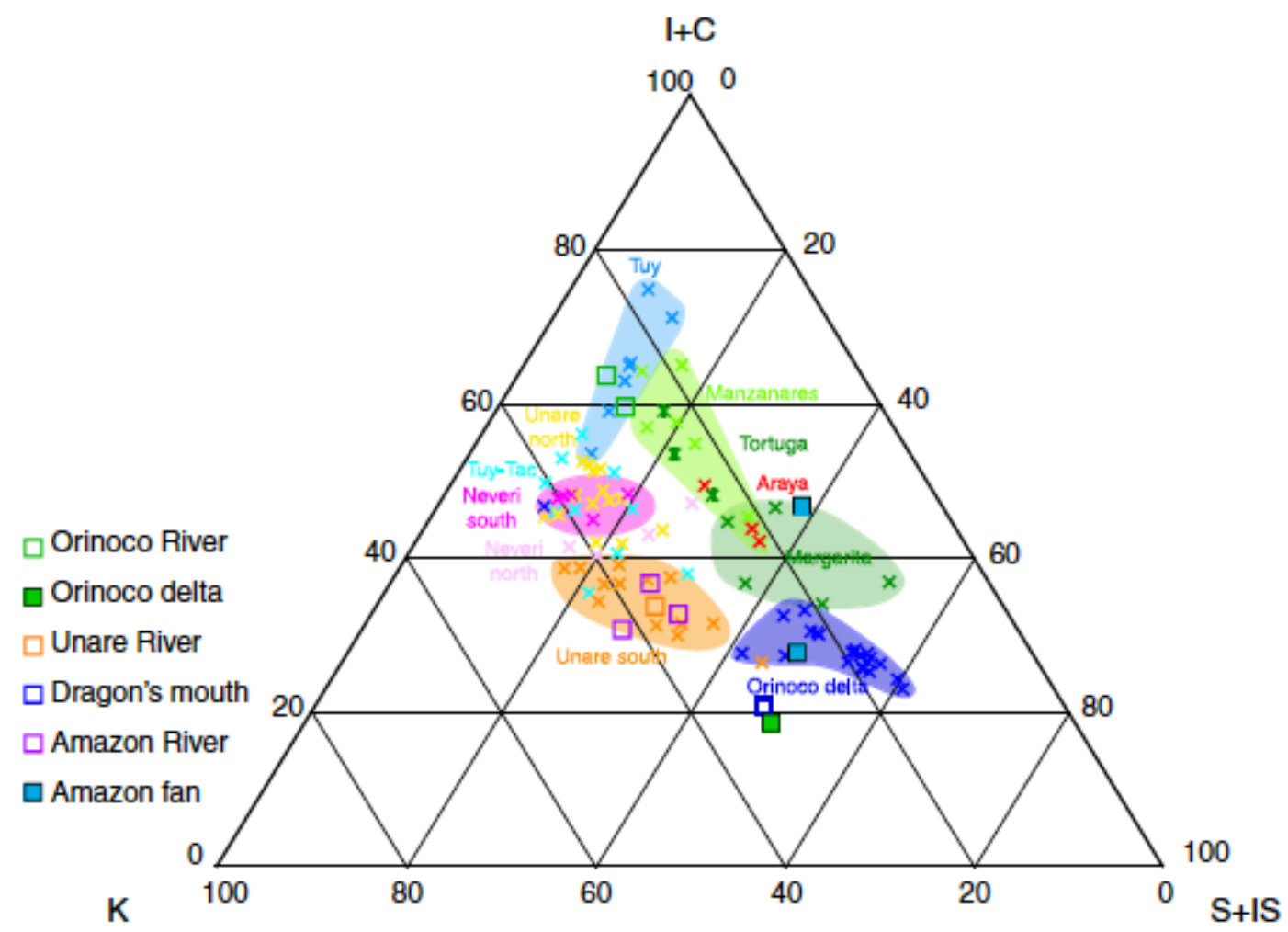

Figure 6. Position of the main geographical areas in a ternary diagram: $\mathrm{I}+\mathrm{C}=$ illite + chlorite, $\mathrm{S}+\mathrm{IS}=$ smectite + regular illite-smectite mixed layers, $\mathrm{K}=$ kaolinite. Orinoco River mouth from Parra et al. [1997] and Pujos et al. [1997]; Orinoco plume from Gibbs [1977]; Unare River from this study; Dragon's mouth from Pujos et al. [1997]; Amazon River mouth from Gibbs [1967]; and Amazon fan from Debrabant et al. [1997] and Rühlemann et al. [2001]. 
Table 1. Clay Mineral Composition (in \% of the clay-mineral fraction) of the Amazon River Mouth, Amazon Fan, Orinoco River, Dragon's mouth, and Cariaco Basin from the Literature, Averaged Clay-Mineral Composition ${ }^{\mathrm{a}}$ of the Orinoco Delta and of the Main Geographical Areas Within Cariaco Basin

\begin{tabular}{|c|c|c|c|c|c|c|c|c|c|}
\hline Area & $\mathrm{S} \%$ & $I \%$ & $\mathrm{C} \%$ & $\mathrm{~K} \%$ & IS $\%$ & $\mathrm{I} /(\mathrm{C}+\mathrm{K})$ & LS & $\operatorname{CSF}(\%)$ & References \\
\hline Amazon River mouth & $27-32$ & $25-35$ & $<10$ & $35-42$ & - & - & - & - & Gäbs, $[1967]$ \\
\hline Amazon Fan & $33-47$ & $20-35$ & $8-12$ & $15-25$ & - & - & - & - & Debrabant et al. [1997], Rühlemann et al. [2001] \\
\hline Orinoco River Mouth & $7-13$ & $43-47$ & 16 & 27 & - & - & - & - & Parra et al. [1997], Pujos et al. [1997] \\
\hline Dragon's mouth & 35 & 21 & & 32 & - & - & - & - & Pujos et al. [1997] \\
\hline Cariaco Basin & 5 & 65 & 5 & 24 & - & - & - & - & Biscaye [1965] \\
\hline Cariaco Basin & 14 & 44 & 7 & 33 & - & - & - & - & Biscaye [1965] recalculated \\
\hline Cariaco Basin & 58 & 22 & 6 & 14 & - & - & - & - & Clayton $s$ [1999] \\
\hline Unare River mouth & 29 & 20 & 14 & 37 & - & 0.39 & 0.69 & - & This study \\
\hline Orinoco delta & 51 & 18 & 10 & 21 & - & 0.59 & 0.44 & 15.0 & This study \\
\hline Tuy & 12 & 46 & 18 & 24 & 0 & 1.10 & 3.96 & 13.5 & This study \\
\hline Unare south & 28 & 20 & 15 & 37 & 0 & 0.38 & 0.79 & 12.3 & This study \\
\hline Nevcri north & 20 & 29 & 15 & 35 & 2 & 0.61 & 1.50 & 11.3 & This study \\
\hline Nevari south & 7 & 34 & 13 & 38 & 8 & 0.67 & 5.24 & 10.9 & This study \\
\hline Unare north & 16 & 30 & 17 & 36 & 1 & 0.56 & 1.99 & 10.0 & This study \\
\hline Tuy-Tac & 17 & 29 & 17 & 37 & - & 0.54 & 2.04 & 9.3 & This study \\
\hline Manzanares & traces & 51 & 6 & 22 & 21 & 1.83 & $>8.66$ & 7.7 & This study \\
\hline Araya & 19 & 34 & 11 & 22 & 14 & 1.01 & 1.91 & 7.0 & This study \\
\hline Margarita & 35 & 26 & 14 & 19 & 5 & 0.88 & 0.74 & 5.6 & This study \\
\hline Tortuga & 14 & 39 & 15 & 24 & 8 & 0.99 & 1.75 & 2.5 & This study \\
\hline
\end{tabular}

${ }^{\mathrm{a}} \mathrm{S}=$ smectite; $\mathrm{I}=$ illite; $\mathrm{C}=$ chlorite; $\mathrm{K}=$ kaolinite; $\mathrm{IS}=$ regular illite-smectite mixed layers; $\mathrm{I} /(\mathrm{C}+\mathrm{K})=$ illite $/($ chlorite + kaolinite $)$ ratio; $\mathrm{I} / \mathrm{S}=$ illite/smectite ratio; $\mathrm{CSF}=$ clay-size fraction $(\%) ; \operatorname{Tr}=$ trace amounts.

Table 2. Descriptive Statistics ${ }^{\mathrm{a}}$ of Clay Minerals

\begin{tabular}{lclcccccccccc}
\hline Variable & Min. & Max. & Mean & Median & Range & Sk. & K. & Variance & CV & SD & Lt & $p$-value \\
\hline Smectite & 0 & 45 & 17.5 & 17 & 45 & 0.43 & 3.12 & 105.51 & 58.67 & 10.27 & 0.09 & 0.21 \\
Illite & 12 & 60 & 31.8 & 31 & 48 & 0.70 & 3.17 & 108.83 & 32.82 & 10.43 & 0.14 & $1.510^{-3}$ \\
Chlorite & 5 & 24 & 14.9 & 15 & 19 & -0.63 & 3.58 & 14.75 & 25.77 & 3.84 & 0.13 & $6.210^{-4}$ \\
Kaolinite & 11 & 44 & 31.8 & 34 & 33 & -0.48 & 2.23 & 64.54 & 25.27 & 8.03 & 0.15 & $3.510^{-4}$ \\
IS & 0 & 32 & 4.0 & 1 & 32 & 2.12 & 7.31 & 43.64 & 165.74 & 6.61 & 0.29 & $<2.210^{-16}$ \\
CSF & 1.75 & 19.33 & 9.8 & 10 & 18 & -0.28 & 2.75 & 14.65 & 38.46 & 3.83 & 0.09 & 0.18 \\
\hline
\end{tabular}

${ }^{\mathrm{a}} \mathrm{IS}=$ regular illite-smectite mixed layers; $\mathrm{CSF}=$ clay-size fraction in $\%$; Min. $=$ minimum value; Max. maximum value; $\mathrm{Sk} .=$ skewness; $\mathrm{K} .=$ kurtosis; $\mathrm{SD}=$ Standard deviation; $\mathrm{CV}=$ Coefficient of variation; $\mathrm{Lt}=$ results of Lilliefors test for normality; $\mathrm{p}$-value is significance of test. If the result of the test is significant, then the hypothesis that the respective distribution is normal should be rejected. 
Table 3. Semi-variogram Models and Model Parameters for Clay Minerals and Ratios ${ }^{\mathrm{a}}$

\begin{tabular}{|c|c|c|c|c|c|c|}
\hline Variable & Model & $C_{0}$ & Spatial component & $\mathrm{C}$ & {$\left[\mathrm{C}_{\alpha} /\left(\mathrm{C}_{0}+\mathrm{C}\right)\right] 10^{2}$} & Spatial Dependency \\
\hline & & & Distance range (degree) & & $\begin{array}{l}\text { Proportion of the nugget value } \\
\text { from the variogram sill }\end{array}$ & \\
\hline Smectite & $\operatorname{Exp}$ & 10 & 1.359 & 137.4 & 6.79 & Strong \\
\hline Illite & Gaul & 18 & 1.056 & 166.8 & 9.74 & Strong \\
\hline Chlorite & Gau & 4 & 3.308 & 60.7 & 6.18 & Strong \\
\hline Kaolinite & Gaul & 20 & 2.716 & 233.2 & 7.90 & Strong \\
\hline IS & Gaul & 3 & 2.113 & 124.1 & 2.36 & Strong \\
\hline CSF & Gau & 8 & 1.667 & 157.9 & 4.82 & Strong \\
\hline
\end{tabular}

${ }^{a} \mathrm{IS}=$ regular illite-smectite mixed layers; $\mathrm{I} /(\mathrm{C}+\mathrm{K})=$ illite/(chlorite + kaolinite $)$ ratio; $\mathrm{I} / \mathrm{S}=$ illite/smectite ratio; $\mathrm{CSF}=$ clay-size fraction in \%; Exp $=$ exponential; Gau $=$ Gaussian; $\mathrm{C} 0=$ nugget; $\mathrm{C}=$ Sill; the spatial dependency is classified as strong $\left([\mathrm{C} 0 /(\mathrm{C} 0+\mathrm{C})] 10^{2}<25 \%\right)$ 